\title{
Managing passengers' experience through mobile moments
}

\section{Article}

\author{
Accepted Version
}

Creative Commons: Attribution-Noncommercial-No Derivative Works 4.0

Inversini, A. (2017) Managing passengers' experience through mobile moments. Journal of Air Transport Management, 62. pp. 78-81. ISSN 0969-6997 doi:

https://doi.org/10.1016/j.jairtraman.2017.03.009 Available at https://centaur.reading.ac.uk/75354/

It is advisable to refer to the publisher's version if you intend to cite from the work. See Guidance on citing.

Published version at: https://doi.org/10.1016/j.jairtraman.2017.03.009

To link to this article DOI: http://dx.doi.org/10.1016/j.jairtraman.2017.03.009

All outputs in CentAUR are protected by Intellectual Property Rights law, including copyright law. Copyright and IPR is retained by the creators or other copyright holders. Terms and conditions for use of this material are defined in the End User Agreement.

\section{www.reading.ac.uk/centaur}

\section{CentAUR}

Central Archive at the University of Reading

Reading's research outputs online 


\title{
Managing Passengers' Experience Through Mobile Moments
}

\begin{abstract}
Travelers' experience is dramatically affected by the use of digital technologies. On the one side, travel companies use them to support management and marketing practices with the purpose of fostering efficiency and ultimately increase competitiveness. On the other side, travelers heavily rely on their digital devices to organize, personalize and to a certain extent 'live' their travelling experience. Within this scenario, mobile devices are seen from both ends as crucial mean for location and context based interactive communication. Mobile devices are here discussed as personalization tool for leisure air passengers' experiential journey in an airport starting from customers' journey analysis, along with information sources used within the whole journey.
\end{abstract}

Keywords: customer journey, mobile moment, experience mapping.

\section{Background}

Over the years, researchers have tried to define the concept of experience which, anyway, remains loose given the complexity and multifaceted nature of the notion (Same \& Larimo, 2012). Schmitt (2011) described the customer experience as multidimensional yet holistic concept, composed by multiple dimensions of how a human's mind works. Millard, (2006) defined the experience as an expectation gap between promised services and the result of what the customer receives. Morgan, Lugosi, and Ritchie (2010) agree and describe the customer experience as a continuous process of diminishing the space between promises a company gives to its consumers and the distributed experience. Academics and practitioners agree that the creation of exclusive and memorable experiences creates added value for consumers and generates competitive advantages (Morgan et al., 2010) for the company leading to customers' satisfaction and loyalty (Cetin \& Dincer, 2014).

Within this context mobile technologies are transforming travelers' experience, by enabling the co-creation, co-delivery, and co-consumption of personalized activities (Neuhofer et al., 2013). Recent evolutions indicate that mobile devices are becoming travel buddies (Tussyadiah, 2013) and their use is profoundly influencing the different phases of a travelers' journey (Wang \& Fesenmaier, 2013). The contextual and mobile interactions (Wang et al., 2014) between consumers and the travel and tourism providers are rapidly germinating into mobile moments (Stickdorn \& Schneider, 2009) where a new purposeful connection is created between travelers and the tourism organization. Therefore services providers have, for the first time ever, the possibility to establish meaningful relationships with their customers while the actual experience is taking place (Tussyadiah, 2015) by using mobile touchpoints as bi-directional point of interaction (Inversini et al., 2016) with consumers. Google refers to this rising phenomenon as "micro-moment": micro-moments occur when people reflexively turn to a device - increasingly a smartphone - to act on a need to learn something, do something, discover something, watch something, or buy something (Ramaswamy, 2015).

Customer experience in the aviation sector is regarded as one of the major issues for the industry (ACI EUROPE, 2014) which, is always investigating customers' perceptions of service quality (Fodness \& Murray, 2007). New technologies are seen as a key tool to support and enhance customer experience (Tnooz, 2013) with personal devices such as 
mobile phones but also thanks to digital self-services kiosks and mobile check-in. Furthermore, a CISCO study (Fattah et al., 2009) recognized mobile devices as one of the biggest opportunity for enhancing customer experience in the airport environment.

This research argues that mobile technology can give a personal added value (being it hedonic or utilitarian) to passengers only if the customers' journey (Maechler et al., 2016) and the possible (mobile) touchpoint are identified and triggered to establish meaningful relationships between the company and the passengers.

\section{Methodology}

This short article presents a preliminary research on mobile touchpoints in airport passengers' experience. Moving from the academic concepts of customer experience (e.g. Millard, 2006) and mobile touchpoints (e.g. Inversini et al., 2016) as well as from relevant industry-based reports (e.g. ACI EUROPE, 2014) this study was designed to tackle three primary objectives: (i) to identify experiential activities performed by airport passengers before, during and after their customers' experience at the airport terminal; (ii) to identify information sources used by airport passengers before, during and after their customers' experience at the airport terminal; (iii) to generate an initial understanding of the customers' journey and possible mobile touchpoints to create valuable connection between travelers and the airport managers.

The research adopts a qualitative approach based on 170 semi-structured interviews to air travelers. Interviews were collected in two international locations served by international airports. To be considered eligible for the research an interviewee should have taken at least one flight in the year before the interview (interviews took place March and April 2016) from the international airport of the given location. This exploratory research only considered leisure travelers as relevant for the sample. After a series of demographic and profiling questions, interviewees were asked about their travel experience before coming to the airport, at the airport and after leaving the airport. Particularly they were asked about the five main activities and the five main information sources used in these their last trips.

Results were then analyzed with computer-based content analysis thanks to the webbased service Voyant (voyant-tools.org). Answers were reduced to lemmas in order to (i) examine lemmas frequency within the answers and (ii) assess key concepts proximity (Flament, 1981). Results were then plotted into a customers' journey map. In order to compile a relevant customer journey map, secondary resources have been used such as the hallmark report "Guidelines for Passenger Services at European Airports" (ACI EUROPE, 2014), the CISCO report "Smart Airports: Transforming Passenger Experience To Thrive in the New Economy" (Fattah et al., 2009) and the preliminary results of "PassMe - Fast Airport, Stress Free Journey" project funded by the European Commission (PASSME, 2016).

\section{Results}

The majority of respondents were male travelers who travel 1- 5 times per year. Most of the respondents in our sample travel with a mobile device (54\%), and some with laptop $(23 \%)$ and tablet $(21 \%)$. Wearable devices, such as smart watches, are still in their infancy with only $3 \%$ of the interviewees travelling with them.

Travelers were asked the five main activities and the five main information sources used before coming to the airport, at the airport and after leaving the airport. Figure $1 \mathrm{a}, 1 \mathrm{~b}$ 
and 1c present the proximity of higher frequency terms with regards to the activities performed in the three moments.

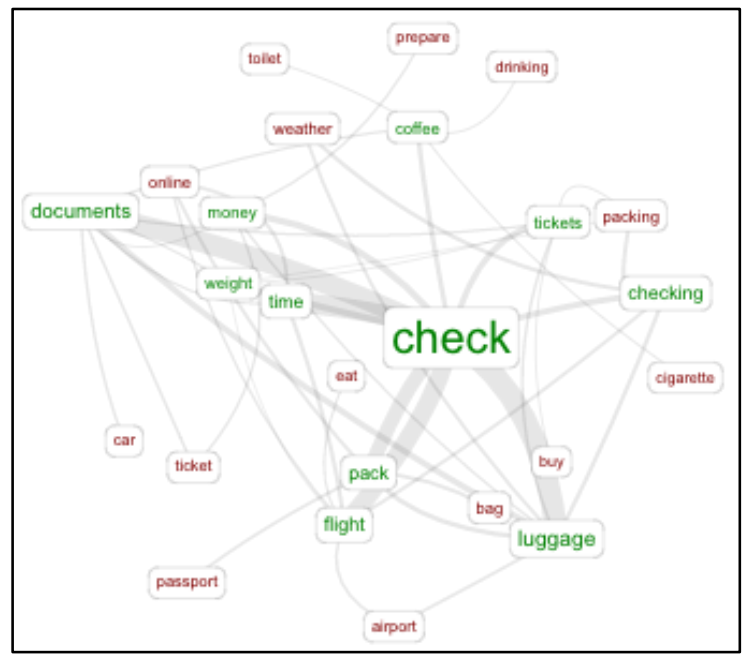

(Figure 1a - Proximity of higher frequency terms before airport experience)

The sample described the moments before going to the airport (Figure 1a) with activities mainly related with checking all the issue related the trip (e.g. passport, luggage) and planning their way to the airport (e.g. private transportation, public transportation, taxi etc.). Stronger lemmas proximity ties link the core concept of 'check' to the words 'luggage', 'documents', 'flight', 'time' and 'pack' highlighting a series of organizational activities carried out by air travelers. Most frequent words in the corpus are: check $(n=212)$; luggage $(n=51)$; documents $(n=41)$; flight $(n=34)$. Main information sources used in this stage are the airport website $(13 \%$, e.g. to reserve a car park), the carrier website (19\%, e.g. to check ticket and luggage allowance) and in general transportation and navigation website $(13 \%$, e.g. how to get to the airport transport websites and/or google maps). Activities related to checking the destination are also popular (e.g. weather checking).

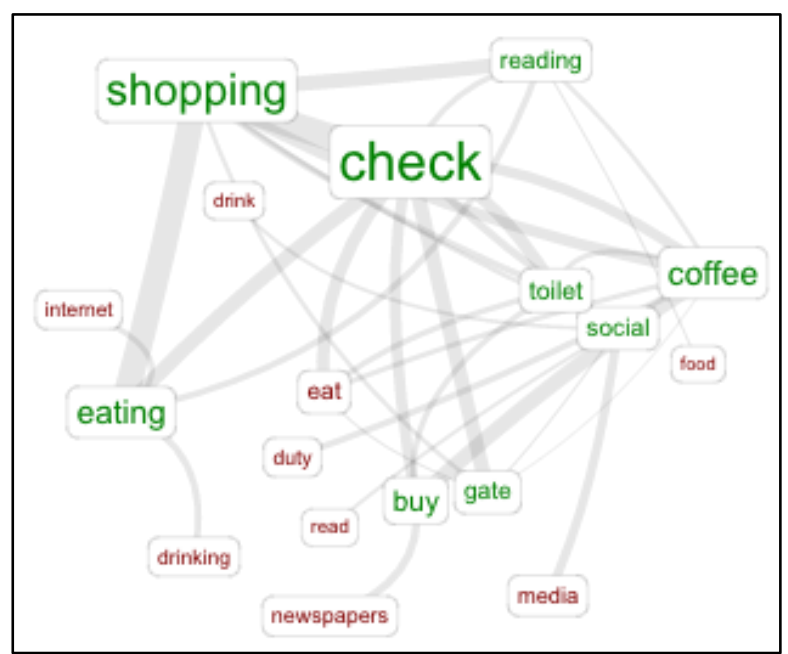

(Figure 1b - Proximity of higher frequency terms during airport experience)

While at the airport (Figure 1b), main activities refer to personal relaxation and passing time (e.g. shopping, eating, reading) and checking the information provided by the airport (e.g. gate). Proximity ties link the core concept of 'check' to 'gate', 'eating' and 'buy'. There is however a strong relevance of the concept of 'shopping' which is linked to 'check' but also to 'eating' and 'reading'. This suggests that besides organizational 
activities, passengers also enjoy their time at the terminal engaging in more hedonic activities. Most frequent words in the corpus are: check ( $n=91)$; shopping $(n=68)$; coffee $(n=42)$; eating $(n=41)$; eat $(n=36)$. Main information sources are media in the airport ( $44 \%$ - e.g. screens, totem etc.) and the internet in general (23\%). Traditional media do play a role in this phase (e.g. 7\% newspaper and magazines). The airport website almost completely disappeared (2\%), while the carrier website is still visited (5\%).

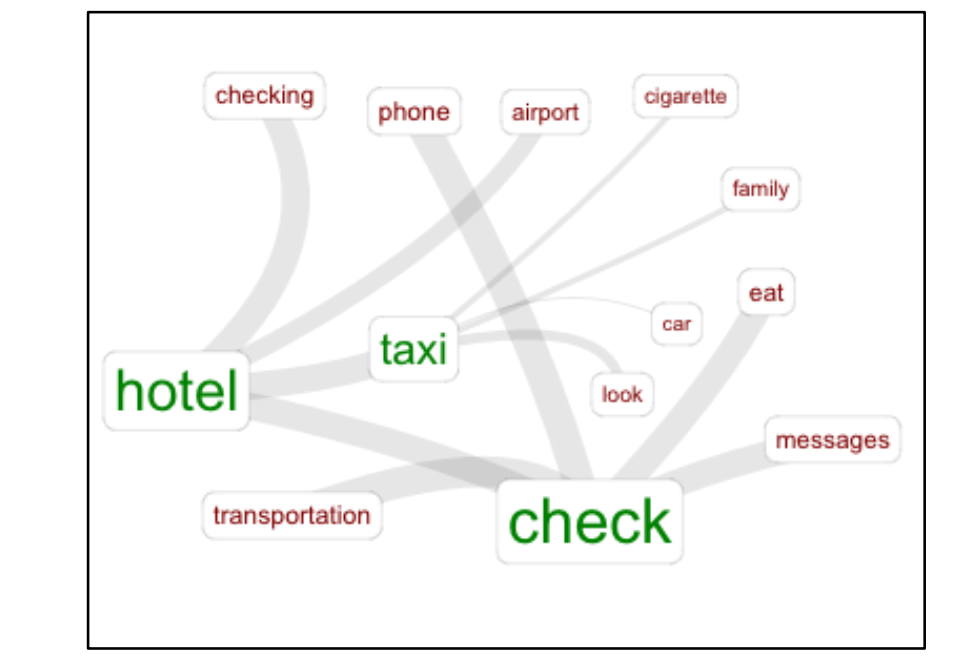

(Figure 1c - Proximity of higher frequency terms after airport experience)

Once boarded and at the destination (Figure 1c), main activities refer to organize the transportation to the final destination (e.g. transportation, taxi etc.) and/or to the hotel. Passing time (e.g. smoking) and activities such as eating and drinking are also popular. Strong proximity ties link the word 'check' with 'transportation', 'messages', 'eat' and 'phone'. There is also the emergence of the lemma 'hotel' linked with taxi, and check/checking. Functional and organizational activities emerge as core occupation of the travellers in this phase. Most frequent words in the corpus: check ( $\mathrm{n}=65)$; hotel $(n=57)$; taxi $(n=37)$; look $(n=29)$; transportation $(n=26)$. Main information sources are related to transportation and navigation (31\%) and passing time browsing the internet $(30 \%)$.

\section{Implications}

Primary research results were confronted and integrated with (i) the synthetic view of the passengers end-to-end journey (ACI EUROPE, 2014), (ii) a series of codified atomic activities passengers do within their airport experience (CISCO - Fattah et al., 2009) and (iii) an investigation about the stress moments of airport users (PASSME, 2016 preliminary results), to generate a customers' journey map offering a synthetic view of passengers' experience at the airport (Figure 2). 


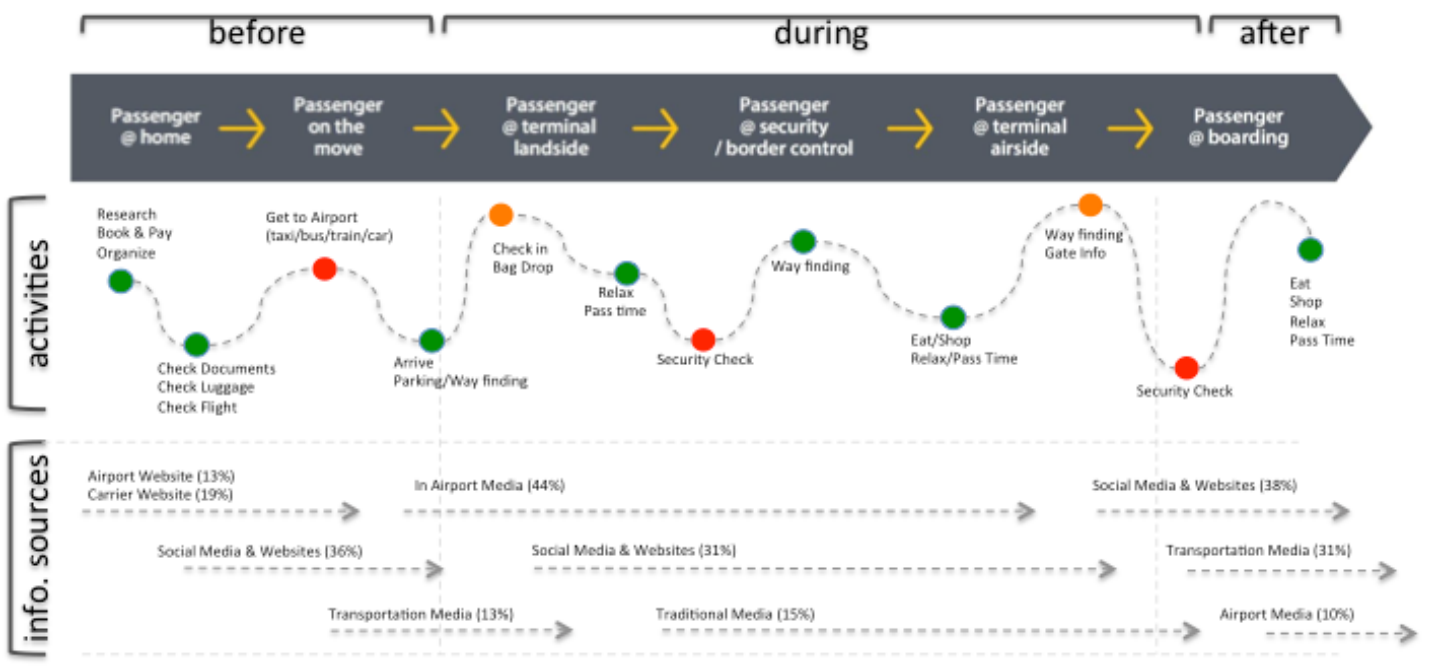

(Figure 2 - Customer Journey Map: Activities and Information Sources)

The synthetic view proposed in figure 2 highlights four main clusters of activities passengers do before coming to the airport (i.e. at home and on the move): (i) research, book, pay and organize the trip, (ii) check documents, luggage and flight, (iii) go to airport (with bus, taxi, train, car), (iv) parking and way finding. Step number three is the one that generates more stress for the passenger. Before coming to the airport passengers look to a variety of media. Airport website, carrier websites and social media are the most used information sources and may offer opportunities for creating mobile touchpoints between the passengers and the airport.

During their stay at the airport passengers engages with a series of practical activities related with (i) check in and bag drop, (ii) security check, (iii) relaxing and pass time, (iv) eat and shop, (v) way finding - landside and airside- and gate information with different levels of stress (notably security check brings lots of stress to passengers followed by check-in, bag drop and gate finding). As for what concerns the information sources, in this moment passengers are completely relying on airport media and the web. This, as noted by CISCO already in 2009 (Fattah et al., 2009), can offer endless possibilities of engagement with customers at practical (e.g. way finding) and commercial (e.g. marketing) way.

Once boarded and at the final destination passengers' activities refer to (i) security check and luggage claim (that brings lots of stress) and (ii) eat, shop, relax and pass time. At this stage there is a prevalence of digital media (social media and website), transportation media and airport media as information sources.

\section{Conclusions}

Passengers go through a series of different activities and moments during their customer journey and, as shown by the research, they rely on different information sources (Wang et al., 2014). Smartphones, can play a strategic and tactical role within the customer journey (Tussyadiah, 2015) by enabling constant connection between consumers and organization via mobile touchpoints (Inversini et al., 2016) germinating in customers' mobile moments. Relevant information should be delivered in the very moment the customer needs it (i.e. during a given activity), on the device (i.e. 
smartphone) and with the form customer needs (i.e. way finding) to create a positive connection between the passenger and the airport or the organization.

Within the presented customer journey there are two issue that can be further noticed: (i) the constant presence of social media as information source: a structured approach towards listing to social media could lead to more personalized interaction with customers; (ii) the power of airport media while the customer is on land and air side: in this may support a customization of the airport experience leveraging these media. Smartphone could enter the picture as a personal devices enhancing the possibility of experience co-creation (Neuhofer et al., 2013).

\section{Reference}

ACI EUROPE. (2014). Guidelines for Passenger Services at European Airports (p. 120). Brussels: ACI EUROPE (Airports Council International). Retrieved from https://www.aci-europe.org/policy/positionpapers.html?view=group\&group $=1 \& \mathrm{id}=5$

Cetin, G., \& Dincer, F. I. (2014). Influence of customer experience on loyalty and word-of-mouth in hospitality operations. Anatolia, 25(2), 181-194.

Fattah, A., Lock, H., Buller, W., \& Kirby, S. (2009). Smart Airports: Transforming Passenger Experience To Thrive in the New Economy. Cisco Internet Business Solutions Group (IBSG). Retrieved from http://www.cisco.com/c/dam/en_us/about/ac79/docs/pov/Passenger_ Exp_POV_0720aFINAL.pdf

Flament, C. (1981). L'analyse de similitude: une technique pour les recherches sur les représentations sociales. [Similarity analysis: A technique for researches in social representations.]. Cahiers de Psychologie Cognitive/Current Psychology of Cognition, 1(4), 375-395.

Fodness, D., \& Murray, M. (2007). Passengers' expectations of airport service quality. Journal of Services Marketing, 21(7), 492-506.

Inversini, A., Sit, J., \& Pyle, H. T. (2016). Mapping Mobile Touchpoints in Sport Events. In A. Inversini \& R. Schegg (Eds.), Information and Communication Technologies in Tourism 2016 (pp. 535-547). Springer International Publishing.

Maechler, N., Neher, K., \& Park, R. (2016). From touchpoints to journeys: Seeing the world as customers do | McKinsey \& Company. Retrieved June 23, 2016, from http://www.mckinsey.com/business-functions/marketingand-sales/our-insights/from-touchpoints-to-journeys-seeing-the-worldas-customers-do

Millard, N. (2006). Learning from the "wow" factor - how to engage customers through the design of effective affective customer experiences. $B T$ Technology Journal, 24(1), 11-16.

Morgan, M., Lugosi, P., \& Ritchie, J. R. B. (2010). The Tourism and Leisure Experience: Consumer and Managerial Perspectives. Channel View Publications. 
Neuhofer, B., Buhalis, D., \& Ladkin, A. (2013). Co-creation Through Technology: Dimensions of Social Connectedness. In Z. Xiang \& I. Tussyadiah (Eds.), Information and Communication Technologies in Tourism 2014 (pp. 339352). Springer International Publishing.

PASSME. (2016). PASSME - Results to Date. Retrieved June 23, 2016, from http://www.passme.eu/results-to-date

Ramaswamy, S. (2015). How Micro-Moments Are Changing the Rules. Mountain View: Google Inc. Retrieved from https://www.thinkwithgoogle.com/articles/how-micromoments-arechanging-rules.html

Same, S., \& Larimo, J. (2012). Marketing Theory: Experience Marketing and Experiential Marketing. Presented at the 7th International Scientific Conference, Business and Management, Vilnius.

Schmitt, B. (2011). Experience Marketing: Concepts, Frameworks and Consumer Insights. Now Publishers Inc.

Stickdorn, M., \& Schneider, J. (2009). myService Fellow: gaining genuine customer insights. Presented at the First Nordic Conference on Service Design and Service Innovation, Oslo.

Tnooz. (2013). Airports, airlines and the passenger experience in 2015 [INFOGRAPHIC]. Retrieved June 23, 2016, from https://www.tnooz.com/article/airports-airlines-and-the-passengerexperience-in-2015-infographic/

Tussyadiah, I. (2013). When Cell Phones Become Travel Buddies: Social Attribution to Mobile Phones in Travel. In L. Cantoni \& Z. (Phil) Xiang (Eds.), Information and Communication Technologies in Tourism 2013 (pp. 82-93). Springer Berlin Heidelberg.

Tussyadiah, I. P. (2015). The Influence of Innovativeness on On-Site Smartphone Use among American Travelers: Implications for Context-based Push Marketing. Journal of Travel \& Tourism Marketing, 0(0), 1-18.

Wang, D., \& Fesenmaier, D. R. (2013). Transforming the Travel Experience: The Use of Smartphones for Travel. In L. Cantoni \& Z. (Phil) Xiang (Eds.), Information and Communication Technologies in Tourism 2013 (pp. 5869).

Wang, D., Xiang, Z., \& Fesenmaier, D. R. (2014). Smartphone Use in Everyday Life and Travel. Journal of Travel Research, 0047287514535847. http://doi.org/10.1177/0047287514535847 